\title{
Enzymatic Hydrolysis of Salmon Oil by Native Lipases: Optimization of Process Parameters
}

\author{
Patrícia de O. Carvalho, ${ }^{* a}$ Paula R. B. Campos, ${ }^{a}$ Maximiliano D’Addio Noffs, ${ }^{a}$ \\ Patrícia B. L. Fregolente ${ }^{b}$ and Leonardo V. Fregolente ${ }^{b}$
}

\author{
${ }^{a}$ Universidade São Francisco, Av. São Francisco de Assis, 218, 12916-900 Bragança Paulista-SP, Brazil \\ ${ }^{b}$ Faculdade de Engenharia Química, Universidade Estadual de Campinas, 13081-970 Campinas-SP, Brazil
}

\begin{abstract}
Três lipases microbianas nativas (Aspergillus niger, Rhizopus javanicus e Penicillium solitum) foram utilizadas na hidrólise do óleo de salmão (teor de AGPI $n$-3 de 30,1\%) com o objetivo de concentrar o conteúdo de ácidos graxos poliinsaturados $n$-3 (AGPI $n$-3) nos acilgliceróis residuais. A metodologia de planejamento experimental e análise de superfície de resposta foi usada para se chegar às condições otimizadas de cada reação enzimática, utilizando as seguintes variáveis; temperatura $\left(\mathrm{X}_{1}\right)$, quantidade de lipase $\left(\mathrm{X}_{2}\right)$ e taxa de água/óleo $\left(\mathrm{X}_{3}\right)$. Com base nos resultados do planejamento, a lipase de Aspergillus niger foi a mais eficiente na concentração dos AGPI $n-3$, sendo que as condições ótimas de reação foram: concentração de enzima de $500 \mathrm{U} \mathrm{g}^{-1}$ óleo, temperatura $45^{\circ} \mathrm{C}$ e taxa de água/óleo de $2: 1 \mathrm{~m} / \mathrm{m}$ após 24 h de reação. $\mathrm{O}$ grau de hidrólise (60\%) conduziu a um aumento do conteúdo de ácido docosahexaenóico (DHA) de 14,4\% para 34,0\% (enriquecimento de 2,4 vezes) nos acilgliceróis residuais após a hidrólise do óleo de salmão.
\end{abstract}

In an attempt to concentrate the content of $n-3$ polyunsaturated fatty acids ( $n-3$ PUFA) in the residual acylglycerol, salmon oil ( $n$-3 PUFA content of 30.1\%) was hydrolyzed with three kinds of native microbial lipases (Aspergillus niger, Rhizopus javanicus and Penicillium solitum). For each lipase, a response surface methodology was used to obtain maximum PUFA content and to optimize the parameters of enzymatic reactions with respect to important reaction variables; temperature $\left(\mathrm{X}_{1}\right)$, amount of lipases $\left(\mathrm{X}_{2}\right)$ and water/oil ratio $\left(\mathrm{X}_{3}\right)$. Based on these results, optimal reaction conditions were established. Aspergillus niger lipase was the most effective in concentrating $n$-3 PUFA. The degree of hydrolysis (60\%) led to an increase in the docosahexaenoic acid (DHA) content from $14.4 \%$ in the original oil to $34.0 \%$ (2.4-fold enrichment) in the residual acylglycerol under optimum conditions: enzyme concentration of $500 \mathrm{U} \mathrm{g}^{-1}$ oil, reaction temperature of $45^{\circ} \mathrm{C}$ and water/oil mass rate of $2: 1(\mathrm{~m} / \mathrm{m})$ after 24 h reaction.

Keywords: polyunsaturated fatty acid, enzymatic hydrolysis, lipases, hydrolysis degree, experimental design, salmon oil

\section{Introduction}

The $n-3$ polyunsaturated fatty acids (PUFA) are commonly known to play an important role in human health. Eicosapentaenoic acid (C20:5 n-3, EPA) and docosahexaenoic acid (C22:6 $n-3$, DHA) have been shown to be of major importance in the prevention of a number of diseases, including coronary heart disease, inflammation, hypotriglyceridemic effect and diabetes. ${ }^{1-5}$ During the last decade, several studies have shown positive effects of fish oils on cognitive development and vision enhancement in newborns, as well as in young children. ${ }^{6}$ For medical

\footnotetext{
*e-mail: patcarvalho@ saofrancisco.edu.br
}

or dietetic purposes, $n-3$ PUFA may be administered in different forms; as free fatty acids (FFA), as ethyl esters, or as acylglycerols. Some studies indicate that PUFA are most promptly absorbed from the intestines when FFA is given orally, are moderately absorbed as acylglycerols and are poorly absorbed as PUFA ethyl ester. However, free $n-3$ PUFA is oxidized most easily and, moreover, free $n-3$ PUFA is unacceptable as a food. Therefore, acylglycerols are considered to be the most desirable chemical form as food. ${ }^{7}$ Lipases are known to catalyze hydrolysis reactions and have been shown as a good alternative for obtaining PUFA concentrates as acylglycerols. ${ }^{8-11}$ Lipase-catalyzed enzymatic production of EPA and DHA concentrates from fish oil has shown potential in producing a high quality 
product, due to the mild conditions (e.g., neutral $\mathrm{pH}$ and low temperatures) of the process. ${ }^{12}$

Commercial lipases from Candida rugosa (cylindracea), Geotrichum candidum, Humicola lanuginose, Chromobacterium viscosum, and Rhizomucor miehei have been largely used for these purposes. ${ }^{8-11,13,14}$ Few investigations have been carried out to exploit the kinetic properties and applications for native microbial lipases isolated from natural sources. ${ }^{15-17}$

In this paper, we evaluate the catalytic performance of three native lipases produced in our laboratory from Aspergillus niger, Rhizopus javanicus and Penicillium solitum for production of a salmon oil concentrate. In addition, a preliminary optimization to determine the optimal processing parameters for the hydrolysis degree of selected lipases was carried out. Three-factor response surface were employed to optimize the reactive conditions of lipase-catalyzed hydrolysis in order to obtain a maximum hydrolysis degree and acylglycerols rich in $n$-3 PUFA.

The method of process optimization by the response surface methodology is a faster and more economical method for gathering research results than the classical one-variable-at-a-time or full-factorial methods..$^{18,19}$

\section{Experimental}

\section{Chemicals and oil}

Peptone and yeast extract were purchased from Difco Laboratories, (Detroit, MI, USA). The components for culture media, chemical reagents and other solvents were obtained from Merck (Darmstadt, Germany) and from Sigma-Aldrich Chemical Co. in the highest purity available. Low acidity olive oil was purchased at a local market. The salmon oil (saponification value, 185 ; acid value, 0.05 ) was purchased from Campestre Ltda (São Bernardo do Campo, São Paulo, Brazil).

\section{Production and determination of lipases activities}

This study was performed using Aspergillus niger, Rhizopus javanicus and Penicillium solitum lipases produced in our laboratory; these lipases achieved better kinetic properties in previous experiments. ${ }^{15,17}$ The lipases were produced in a basal medium with an initial $\mathrm{pH}$ value of 6.0 and consisted of $2 \%(\mathrm{~m} / \mathrm{v})$ peptone, $0.5 \%(\mathrm{~m} / \mathrm{v})$ yeast extract, $0.1 \%(\mathrm{~m} / \mathrm{v}) \mathrm{NaNO}_{3}, 0.1 \%(\mathrm{~m} / \mathrm{v}) \mathrm{KH}_{2} \mathrm{PO}_{4}, 0.05 \%$ $(\mathrm{m} / \mathrm{v}), \mathrm{MgSO}_{4} \cdot 7 \mathrm{H}_{2} \mathrm{O}$ and $2 \%(\mathrm{~m} / \mathrm{v})$ olive oil. Cultures were grown in Erlenmeyer flasks (500 mL) containing $120 \mathrm{~mL}$ of the growth medium. The cultures were inoculated with $1 \mathrm{~mL}$ of spore suspension $\left(10^{5}-10^{6}\right.$ spores $\left.\mathrm{mL}^{-1}\right)$ and the flasks were stirred on a rotary shaker $(130 \mathrm{rpm})$ at $35^{\circ} \mathrm{C}$ for $72 \mathrm{~h}$. After this period, the cultures were filtered and the supernatants were treated with ammonium sulphate $(80 \%$ saturation). The precipitates were dialyzed in water and lyophilized for use as extracellular crude lipase preparations in powder form. The residual water in the lyophilized lipases was $0.2-0.3 \%(\mathrm{~m} / \mathrm{m})$. Lipase activity were quantified by triolein using olive oil as substrate employing a standard oleic acid curve. ${ }^{20}$ One unit (U) is defined as $1 \mu \mathrm{moL}$ of oleic acid released per minute of reaction. Lipases from $A$. niger with $7.5 \mathrm{U}, R$. javanicus with $6.8 \mathrm{U}$ and $P$. solitum with $4.8 \mathrm{U}$ were used. These lipases were used without further purification.

\section{Hydrolysis reaction and experimental design}

Three experimental designs, based on the $2^{3}$ full factorial, were performed under the same experimental conditions for each lipase produced (A. niger, R. javanicus and P. solitum) in order to verify the power of hydrolysis of each native lipase using salmon oil. Reaction mixtures for enzymatic hydrolysis were carried out according to the experimental conditions in Table 1. Conical flasks $(250 \mathrm{~mL})$ were blanketed with nitrogen and kept sealed throughout the reaction for $48 \mathrm{~h}$. The vessels were stirred in an incubator orbital shaker at $400 \mathrm{rpm}$ at different temperatures. Different ratios of water ( $0.1 \mathrm{~mol} \mathrm{~L}^{-1}$ phosphate buffers) and salmon oil were mixed in the flasks and different amounts of lipase preparations ( $U$ of the enzyme $\mathrm{g}^{-1}$ of oil) were added. The initial water/ oil amount was fixed at $30 \mathrm{~g}$ for all experiments. Statistical optimization experiments for all lipases were carried out according to the $2^{3}$ full factorial designs with 4 center points. The independent variables or factors studied were temperature $\left({ }^{\circ} \mathrm{C} ; \mathrm{X}_{1}\right)$, amount of lipases $\left(\mathrm{U} ; \mathrm{X}_{2}\right)$ and water/ oil mass ratio $\left(\mathrm{m} / \mathrm{m} ; \mathrm{X}_{3}\right)$. Response for the dependent variable studied was the degree of hydrolysis (DH) (\%). The design matrix for A. niger, $R$. javanicus and $P$. solitum lipases shown in Table 2 was obtained by means of the Statistica 7.0 software. Significance of data was tested using the ANOVA statistical test. The experiments for all lipases were accomplished at four different times $(6,12,24$ and $48 \mathrm{~h})$ in order to observe the kinetic behavior of each reaction using

Table 1. Experimental conditions

\begin{tabular}{llccc}
\hline \multirow{2}{*}{ Variables } & \multicolumn{3}{c}{ Coded variable levels } \\
\cline { 3 - 5 } & & -1 & 0 & +1 \\
\hline $\mathrm{X}_{1}$ & $\mathrm{~T} /{ }^{\circ} \mathrm{C}$ & 35 & 40 & 45 \\
$\mathrm{X}_{2}$ & Enzyme $(\mathrm{U} / \mathrm{g})$ & 100 & 300 & 500 \\
$\mathrm{X}_{3}$ & Water/oil mass rate $(\mathrm{m} / \mathrm{m})$ & $2: 1$ & $1: 1$ & $1: 2$ \\
\hline
\end{tabular}


the different enzymes. Enzymes were deactivated by heating the reaction to approximately $90{ }^{\circ} \mathrm{C}$ for $15 \mathrm{~min}$ in order to interrupt the reaction at a determined time.

\section{Separation of reaction products}

At the end of each enzymatic reaction, partially hydrolyzed oil containing residual acylglycerols (mono-, di- and triacylglycerols) and released fatty acids fractions were separated by the method described by Shimada et al. ${ }^{8}$ After hydrolysis by Aspergillus niger lipase, the yield of fatty acids isolated $(\mathrm{g})$ per oil $(\mathrm{g})$ was $0.5-0.7$.

\section{Determination of degree of hydrolysis $(\mathrm{DH})$}

Degree of hydrolysis (DH) was determined by measuring the acid value of both unhydrolyzed (original oil) and hydrolyzed oil at different treatment times $(6,12,24$ and $48 \mathrm{~h}$ ) and the saponification value of unhydrolyzed oil, according to the American Oil Chemists' Society methods. ${ }^{21}$ Blanks (no enzyme) were determined for each treatment. DH was calculated according to the following equation:

DH $(\%)=\frac{\text { acid value }(\text { hydrolyzed oil }- \text { blank at each condition })}{\text { saponification value }(\text { original oil })-\text { acid value (original oil) }} \times 100$

Acid values indicate relative amount of free fatty acids released by the hydrolysis reaction, as measured by the $\mathrm{mg}$ of potassium hydroxide necessary to neutralize fatty acids in $1 \mathrm{~g}$ of salmon oil.

\section{Determination of fatty acid composition}

Fatty acids in unhydrolyzed salmon oil, residual acylglycerols and liberated fatty acid fractions were converted after hydrolysis into fatty acid methyl esters (FAME), according to the method of Hartman et al., ${ }^{22}$ and their compositions were determined by gas chromatography (GC). A Chrompack gas chromatograph (CP-9001) equipped with a flame ionization detector and a CP-Sil 88 capillary column (Chrompak, WCOT Fused Silica $50 \mathrm{~m} \times 0.25 \mathrm{~mm}$ i.d.; split ratio, 100:1) were used for analyzing FAME. The initial temperature of the column was $50{ }^{\circ} \mathrm{C}$ for $2 \mathrm{~min}$ and then the temperature was increased at a rate of $10{ }^{\circ} \mathrm{C} \min ^{-1}$ up to $210^{\circ} \mathrm{C}$; hydrogen was used as a carrier gas. The temperature of the injector was $220^{\circ} \mathrm{C}$ and the detector's temperature was $250^{\circ} \mathrm{C}$. Fatty acids were identified by comparing the times of retention of the components present in each sample with the times of retention of the components present in the standard FAME Mix C4-C24 (Supelco).

\section{Results}

\section{Degree of hydrolysis}

A three-factor response surface methodology (RSM) with 4 center points was employed to study the degree of hydrolysis (DH) by lipase-catalyzed synthesis of salmon oil for each native lipase. Experimental results of DH for catalyzed-hydrolysis reactions with salmon oil for each RSM using A. niger, $R$. javanicus and $P$. solitum lipases are given in Table 2. All the reactions were accomplished at four different times (6, 12, 24 and $48 \mathrm{~h}$ ), although only results for the $48 \mathrm{~h}$ reaction were analyzed statistically.

DH's of salmon oil from different lipases, conditions of run and reaction times are shown in Figure 1. In general, salmon oil was hydrolyzed rapidly during the initial $12 \mathrm{~h}$. Afterwards, hydrolysis was more gradual, and only

Table 2. Three-factor designs and responses for lipases from Aspergillus niger, Rhizopus javanicus and Penicillium solitum

\begin{tabular}{|c|c|c|c|c|c|c|}
\hline \multirow[t]{2}{*}{ Run } & \multicolumn{3}{|c|}{ Coded value } & \multicolumn{3}{|c|}{ Experimental value $(\mathrm{DH} / \%)^{\mathrm{a}}$} \\
\hline & $\mathrm{X}_{1}$ & $\mathrm{X}_{2}$ & $\mathrm{X}_{3}$ & A. niger & R. javanicus & P. solitum \\
\hline 1 & -1 & -1 & -1 & 19.2 & 12.9 & 2.8 \\
\hline 2 & +1 & -1 & -1 & 21.9 & 6.2 & 1.9 \\
\hline 3 & -1 & +1 & -1 & 44.1 & 29.7 & 5.0 \\
\hline 4 & +1 & +1 & -1 & 57.2 & 20.2 & 3.0 \\
\hline 5 & -1 & -1 & +1 & 4.6 & 7.6 & 3.4 \\
\hline 6 & +1 & -1 & +1 & 4.7 & 5.3 & 1.0 \\
\hline 7 & -1 & +1 & +1 & 6.6 & 9.6 & 2.7 \\
\hline 8 & +1 & +1 & +1 & 7.5 & 6.9 & 1.8 \\
\hline 9 & 0 & 0 & 0 & 12.8 & 7.2 & 3.5 \\
\hline 10 & 0 & 0 & 0 & 17.4 & 7.6 & 3.6 \\
\hline 11 & 0 & 0 & 0 & 15.8 & 7.4 & 2.8 \\
\hline 12 & 0 & 0 & 0 & 14.8 & 8.0 & 3.7 \\
\hline
\end{tabular}

${ }^{\mathrm{a}} \mathrm{DH}=$ degree of hydrolysis after 48 hours of reaction. 
minor increases were shown throughout the 24 and $48 \mathrm{~h}$ time periods. A. niger was the lipase that most effectively hydrolyzed salmon oil ( $c a .60 \%$ of hydrolysis after $24 \mathrm{~h}$ under experimental conditions).

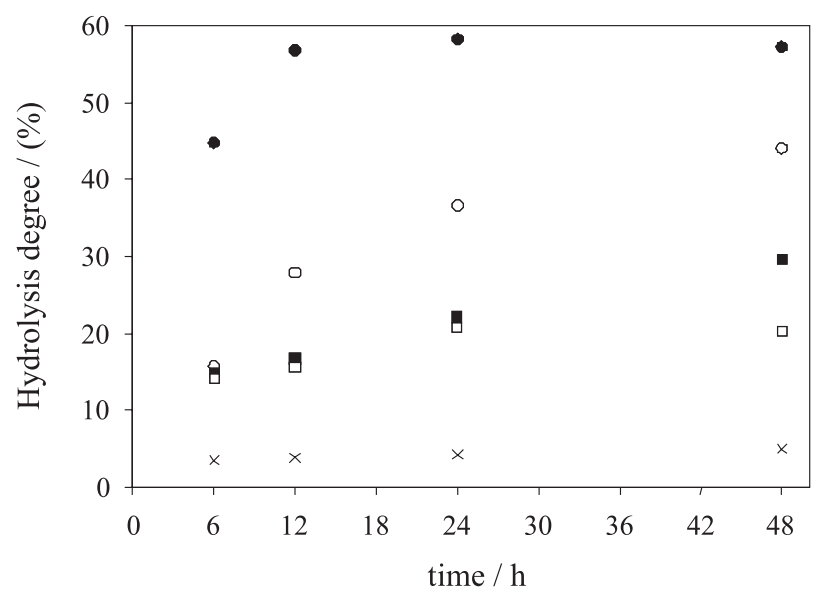

Figure 1. Hydrolysis degree as a function of time (h) for the lipases in different conditions: $(\bullet)$ Aspergillus niger - run 4; (○) Aspergillus niger -

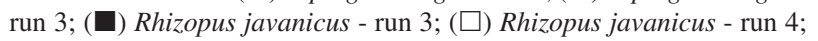
(×) Penicillium solitum - run 3.

Table 3 depicts the analyses of the reaction parameter effects for the DH when the A. niger lipase was used. The concentration of the A. niger lipase, the water/oil mass ratio and the interaction between these parameters significantly affected the DH. Moreover, temperature did not affect the degree of hydrolysis, nor the interactions that involved this parameter. Therefore, these results suggest a linear model whose parameters are mainly $\mathrm{X}_{2}, \mathrm{X}_{3}$ and $\mathrm{X}_{2} \mathrm{X}_{3}$. The coefficients of independent variables determined for the linear model for the $\mathrm{DH}$, when the A. niger lipase was used, are given in equation 1 .

$\mathrm{DH}_{(\mathrm{AN})}=18.33+8.12 \times \mathrm{X}_{2}-14.87 \times \mathrm{X}_{3}-6.92 \times \mathrm{X}_{2} \mathrm{X}_{3}$

The analysis of variance for the $\mathrm{DH}$ model is given in Table 4. Based on the $F$-test, the model (equation 1) is predictive, since the percent of explained variance is high (93.24\%) and the calculated $F$-value (regression/residual) is more than 4 times higher than the critical $F$-value at $95 \%$ of confidence $\left(\mathrm{F}>\mathrm{F}_{0.95,4.7}\right.$ of 6.09$)$. In addition, there is little evidence of a lack of fit for the fitted model, since the calculated $F$-values (lack of fit/pure error) are lower than the critical $F$-value $\left(\mathrm{F}<\mathrm{F}_{0.953 .2}\right.$ of 19.16$)$ at $95 \%$ confidence. ${ }^{23}$

The same analysis of effects of parameters and analysis of variance for $R$. javanicus and $P$. solitum lipases were studied (Tables 5 and 6). Observing the percent of explained variance $\left(\mathrm{R}^{2}\right)$ and $F$-test, the results demonstrate that only
Table 3. Statistical analysis of the operating variables effects for the Aspergillus niger lipase on DH

\begin{tabular}{lcccc}
\hline Factor & Effect & $\mathrm{SE}^{\mathrm{a}}$ & $t$-Value & $p$-Value \\
\hline $\mathrm{X}_{1}$ & 4.20 & 3.2255 & 1.3021 & 0.24963 \\
$\mathrm{X}_{2}$ & 16.25 & 3.2255 & 5.0379 & $0.00397^{\mathrm{b}}$ \\
$\mathrm{X}_{3}$ & -29.75 & 3.2255 & -9.2232 & $0.00025^{\mathrm{b}}$ \\
$\mathrm{X}_{1} \mathrm{X}_{2}$ & 2.80 & 3.2255 & 0.8680 & 0.42505 \\
$\mathrm{X}_{1} \mathrm{X}_{3}$ & -3.70 & 3.2255 & -1.1470 & 0.30325 \\
$\mathrm{X}_{2} \mathrm{X}_{3}$ & -13.85 & 3.2255 & -4.2938 & $0.00776^{\mathrm{b}}$ \\
\hline
\end{tabular}

aStandard Error; ${ }^{\mathrm{b}}$ significant factors $(p$-value $<0.05)$.

Table 4. Analysis of variance (ANOVA) to fit the model presented in equation 1

\begin{tabular}{lrccc}
\hline Source & $\begin{array}{r}\text { Sum of } \\
\text { squares }\end{array}$ & $\begin{array}{c}\text { Degree of } \\
\text { freedom }\end{array}$ & $\begin{array}{c}\text { Mean } \\
\text { squares }\end{array}$ & F-value \\
\hline Regression & 2681.89 & 4 & 670.47 & 25.73 \\
Residues & 182.38 & 7 & 26.05 & \\
Lack of fit & 171.26 & 2 & 34.25 & 9.24 \\
Pure error & 11.12 & 3 & 3.70 & \\
Total & 2864.27 & 11 & & \\
\hline
\end{tabular}

$\mathrm{R}^{2}=0.93 \%$; explained variance: $93.24 \%$.

a first-order polynomial model does not represent the behavior of lipase-catalyzed reactions for these lipases, since the high lack of fit of the models and the regression of the parameters are not significant statistically. Whilst the results of the lipases from $R$. javanicus and $P$. solitum were not statistically significant enough to predict a model, they might be used to observe the behavior of the reactions in function of the parameters studied (temperature, amount of enzyme and water/oil mass ratio) when these native lipases were employed and compared with others in relation to the hydrolysis performance of each.

The next results show the hydrolysis performances of the lipases and their effects on the enzymatic reactions when submitted to different experimental conditions. Figure 2 illustrates the variation of the $\mathrm{DH}$ when, simultaneously, the concentration of lipase and the temperature are analyzed. For A. niger lipase (Figure 2 (a)), practically no influence of the temperature on the response was observed. On the other hand, the increase in temperature decreases the DH for the native lipases from $R$. javanicus and P. solitum, as can be seen in Figures 2 (b) and 2 (c).

Figure 3 shows that, although the three native lipases have differences in the DH (\%), the same behavior was observed in relation to the concentration of lipases and ratio of water and oil in order to increase the DH. Higher DH is reached, increasing the concentration of lipases and increasing the amounts of water in the reaction, simultaneously. 
Table 5. Statistical analysis of the operating variables effects for the Rhizopus javanicus and Penicillium solitum lipase on the DH

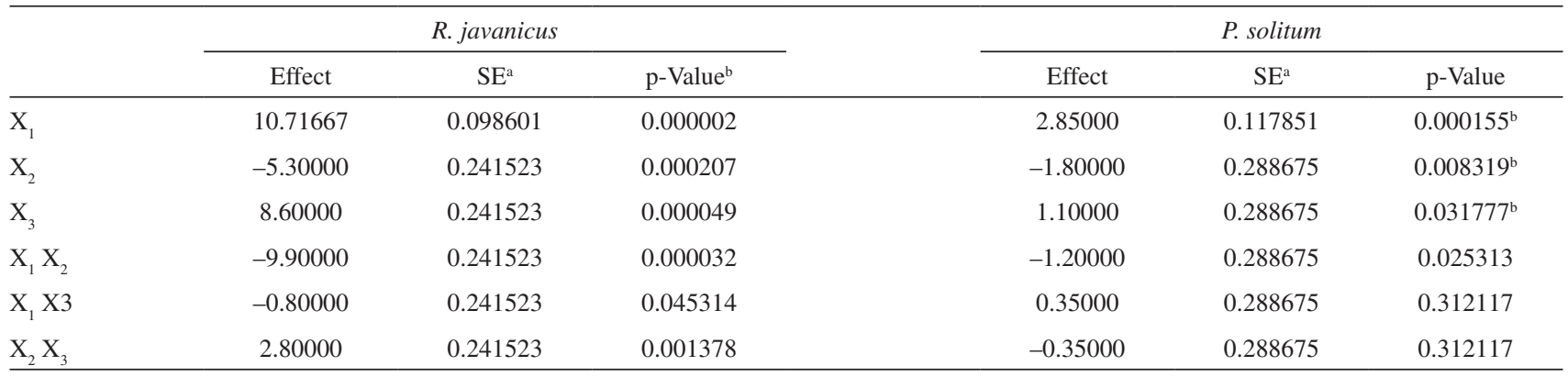

${ }^{a}$ Standard Error; ${ }^{\text {b }}$ significant factors $(p$-value $<0.05)$.

Table 6. ANOVA of regression parameters for the response surface model

\begin{tabular}{lccccc}
\hline & Sum of squares & Pure error & $\mathrm{R}^{2}$ & F-value $\left(\mathrm{F}>\mathrm{F}_{0.95: 4 ;}\right)^{\mathrm{a}}$ & $\mathrm{F}^{2}$-value $\left(\mathrm{F}<\mathrm{F}_{0.95 ; 2 ; 3}\right)^{\mathrm{b}}$ \\
\hline R. javanicus & 570.80 & 0.35 & 0.89 & 14.56 & 19.16 \\
P. solitum & 16.81 & 0.50 & 0.76 & 5.72 & 10.30 \\
\hline
\end{tabular}

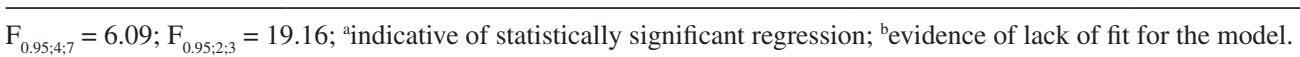
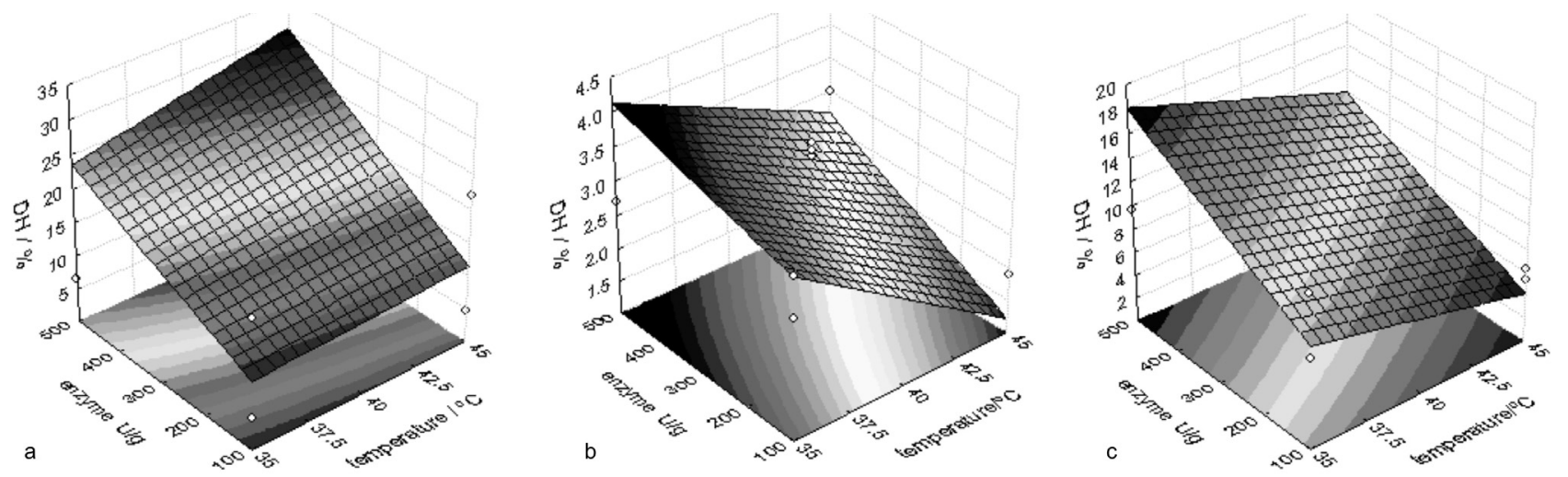

Figure 2. Varying concentrations of lipases and temperature as a function of DH for lipases: a) Aspergillus niger; b) Penicillium solitum; c) Rhizopus javanicus.
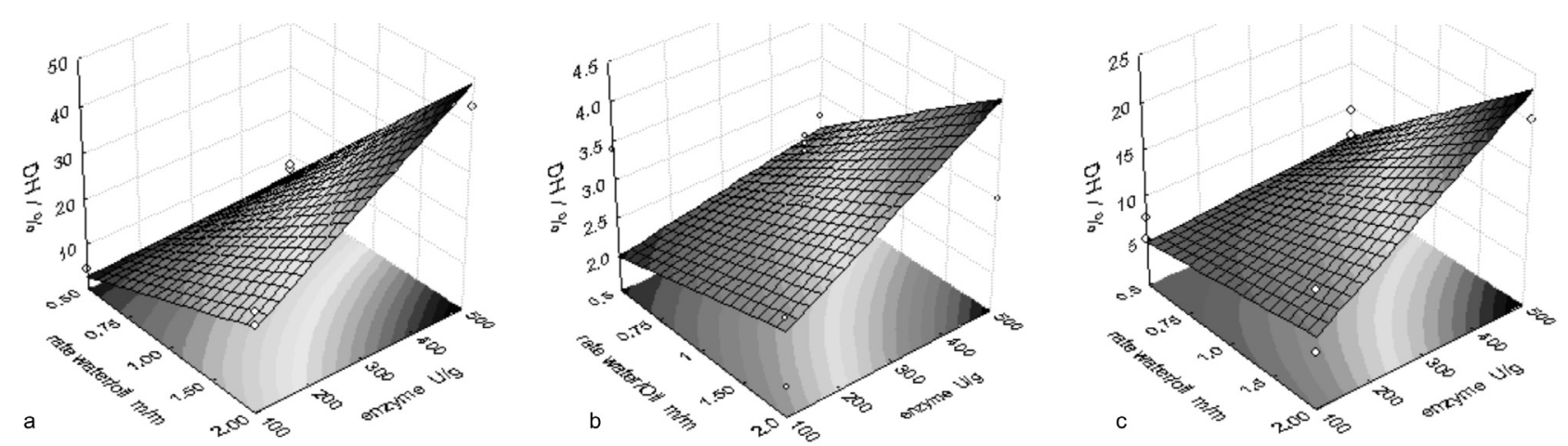

Figure 3. Varying water/oil mass ratio and concentrations of lipases as a function of DH: a) Aspergillus niger; b) Penicillium solitum; c) Rhizopus javanicus. 
Table 7. Composition of the main fatty acids of the reaction product after 45 and $60 \%$ hydrolysis of salmon oil by Aspergillus niger lipase

\begin{tabular}{|c|c|c|c|c|c|}
\hline \multirow[b]{2}{*}{ Fatty acids } & \multirow[b]{2}{*}{ Original oil } & \multicolumn{2}{|c|}{$45 \%$ of hydrolysis ${ }^{a}$} & \multicolumn{2}{|c|}{$60 \%^{\mathrm{b}}$ of hydrolysis ${ }^{\mathrm{a}}$} \\
\hline & & $\begin{array}{l}\text { Hydrolyzed } \\
\text { acylglycerol }\end{array}$ & $\begin{array}{l}\text { Liberated } \\
\text { fatty acids }\end{array}$ & $\begin{array}{l}\text { Hydrolyzed } \\
\text { acylglycerol }\end{array}$ & $\begin{array}{l}\text { Liberated } \\
\text { fatty acids }\end{array}$ \\
\hline $\mathrm{C} 16: 0$ & $9.4 \pm 0.4$ & $5.3 \pm 0.8$ & $15.8 \pm 1.6$ & $4.6 \pm 0.5$ & $14.4 \pm 1.9$ \\
\hline C16:1 & $4.3 \pm 0.3$ & $2.7 \pm 0.4$ & $7.9 \pm 1.4$ & $2.2 \pm 0.3$ & $6.8 \pm 1.3$ \\
\hline $\mathrm{C} 18: 0$ & $3.5 \pm 0.2$ & $1.9 \pm 0.8$ & $4.3 \pm 0.6$ & $2.5 \pm 0.3$ & $4.3 \pm 1.0$ \\
\hline C18:1 & $15.3 \pm 0.4$ & $8.5 \pm 0.4$ & $18.8 \pm 1.5$ & $7.9 \pm 2.1$ & $16.8 \pm 1.7$ \\
\hline $\mathrm{C} 20: 5$ & $15.7 \pm 0.4$ & $16.6 \pm 1.4$ & $10.8 \pm 2.6$ & $11.0 \pm 1.7$ & $17.3 \pm 2.6$ \\
\hline $\mathrm{C} 22: 6$ & $14.4 \pm 0.4$ & $28.7 \pm 2.5$ & $5.1 \pm 0.4$ & $34.0 \pm 2.6$ & $3.9 \pm 0.4$ \\
\hline n-3 PUFA & 30.1 & 45.3 & 15.9 & 45.0 & 21.2 \\
\hline DHA/EPA & 0.9 & 1.7 & 0.5 & 3.0 & 0.2 \\
\hline
\end{tabular}

${ }^{\mathrm{a}}$ Corresponding to $c a .45 \%$ hydrolysis degree after 6 hours of reaction (run 4). ${ }^{\mathrm{b}}$ Corresponding to $c a$. $60 \%$ hydrolysis degree after 24 hours of reaction (run 4).

\section{Fatty acid composition of the reaction products}

The composition of the main fatty acids in the residual acylglycerol and liberated fatty acid fractions after hydrolysis of salmon oil with A. niger lipase are shown in Table 7.

After $45 \%$ hydrolysis ( $6 \mathrm{~h}$ of reaction), the total $n-3$ PUFA content of the residual acylglycerol fraction increased by approximately 1.5 -fold, compared to the original oil, giving a final concentration of approximately $45 \%$. Most of the enrichment was due to DHA, which increased twofold, whereas the EPA content remained relatively constant with no significant differences, compared to the feed oil. This difference in selectivity is reflected in the increased DHA/EPA ratio.

The enrichment of $n$-3 PUFA was compensated by a reduction in the content of $\mathrm{C} 16-\mathrm{C} 18$ saturated and monounsaturated fatty acids. The liberated fatty acid fractions were correspondingly increased in the $\mathrm{C} 16-\mathrm{C} 18$ saturated and monounsaturated fatty acids, with a great depletion in DHA, compared to the feed oil.
When the reaction reached $60 \%$ hydrolysis $(24 \mathrm{~h}$ of reaction), the residual acylglycerol fraction were further enriched in DHA, however the EPA content was reduced. Total $n$-3 PUFA was similar to that found after $45 \%$ hydrolysis, although the DHA/EPA ratio reached approximately three at this stage.

\section{Discussion}

Salmon oil was submitted to hydrolysis by three 1,3-specific lipases from A. niger, $R$. javanicus and $P$. solitum to preserve the long chain $n$-3 PUFA, which are preferentially located at the 2 position on the glycerol backbone. ${ }^{24}$ Due to the several cis-cis unsaturations of PUFA, these molecules are strongly bent, thus enhancing the steric hindrance effect. Therefore, the ester moiety of PUFA-containing acylglycerols is hardly split by lipase, in contrast to saturated and monounsaturated fatty acids (Scheme 1).

From the experimental design using native lipase from A. niger, it was possible to obtain a first order model to

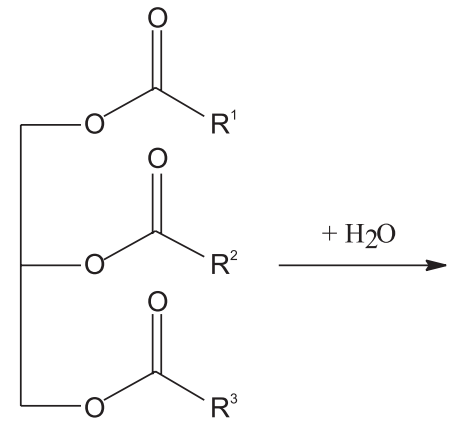

Triacylglycerol<smiles>[R]C(=O)OCC(CO)OC([R])=O</smiles>

1,2(2,3)Diacylglycerol

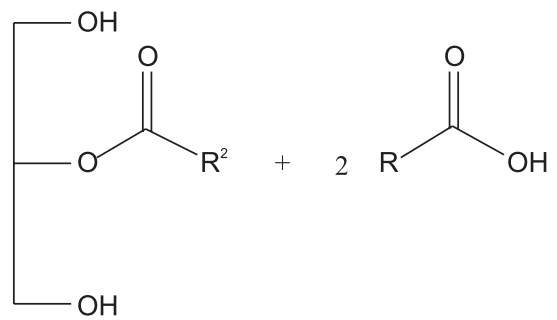

2-Monoacylglicerol
Fatty acids

Scheme 1. Hydrolysis of triacylglycerol catalysed by 1,3-specific lipases. 
optimize the parameters of reaction in function of the $\mathrm{DH}$ of salmon oil. When lipase from A. niger was used, about $60 \%$ of hydrolysis is required after 24 hours of reaction to obtain a high content of DHA and a high DHA/EPA ratio in the unhydrolyzed fraction. Under these optimized conditions, the total $n$-3 PUFA content of the residual acylglycerol fraction was $45 \%$ (34\% DHA + 11\% EPA), approximately 2.4-fold greater than the initial values obtained with the non-optimized system.

In contrast, salmon oil was not hydrolyzed as much with the other lipases; the $R$. javanicus and $P$. solitum lipases achieved just $20 \%$ and $3 \%$ hydrolysis under the same conditions. The temperature significantly influenced the process, causing a 30-40\% decrease in $\mathrm{DH}$ for both the $R$. javanicus and $P$. solitum lipases. A higher reaction temperature $\left(45^{\circ} \mathrm{C}\right)$ caused the denaturation of two lipases. In a previous report, we showed that lipase from A. niger was more thermostable than other native lipases, demonstrating stability at the range 30 and $50{ }^{\circ} \mathrm{C}$ and maintaining at least $60 \%$ of its hydrolytic activity at $60{ }^{\circ} \mathrm{C}$ after 1 h. ${ }^{16}$ A probable explanation for the low lipases activities of $R$. javanicus and $P$. solitum is their enzyme structures, which do not accommodate the esters of PUFA from salmon oil in their active sites.

To our knowledge, this is the first finding of an enzymatic hydrolysis of salmon oil by native lipases. The commercial lipases from Candida rugosa (cylindracea) and Geotrichum candidum are useful for the production of oil containing high concentrations of PUFA. Geotrichum candidum lipase can enrich DHA and EPA and Candida rugosa can enrich DHA, but not EPA. ${ }^{8}$ In general, the $\mathrm{DH}$ is higher in oil hydrolyzed by non-specific lipases (Candida sp.), compared with 1,3-specific lipases (Mucor javanicus, Rhizopus delemar and Aspergillus niger). ${ }^{10,11,25}$ Tanaka et $a l .{ }^{25}$ reported that Candida cylindracea lipase shows low reactivity for DHA esters, and is successful in concentrating DHA in the residual acylglycerol fraction during the hydrolysis ( $c$. $70 \%$ rate) of fish oil. DHA was concentrated from $8.9 \%$ to $30.5 \%$ and EPA was changed from $13.3 \%$ to $9.8 \%$, resulting in $40.3 \%$ of total $n$ - 3 PUFA in the residual acylglycerol fraction of the fish oil.

Some authors have reported that hydrolysis exceeding 50 hours might increase hydrolysis to around $90 \% .{ }^{26}$ In this study, a DH of $60 \%$ and an increase of $50 \%$ in $n$-3 PUFA were reached after $24 \mathrm{~h}$ and no further increase was noted following longer reaction times (data not shown).

Okada and Morrisey (2007) ${ }^{11}$ investigated the production of $n$-3 PUFA concentrate from Pacific sardines using several commercial lipases. Oil hydrolyzed by Aspergillus niger lipase exhibited only a minor increase in DHA content ( $13.6 \%$ to $18.5 \%$ with $250 \mathrm{U}$ after $1.5 \mathrm{~h}$ and to $18.7 \%$ with $500 \mathrm{U}$ after $3 \mathrm{~h}$ ) and no significant changes in EPA content. ${ }^{11}$

Our results clearly demonstrate the superiority of the lipase from Aspergillus niger in the enrichment of DHA by selective hydrolysis of salmon oil, which demonstrated to be a feasible method for the development of salmon oil health products. The experimental design procedure provided a powerful tool to optimize the hydrolysis conditions that permit an important improvement in the degree of hydrolysis of this lipase. Under optimum conditions, a good enrichment of DHA (2.4-fold) was achieved, which is considerably higher than those results previously reported using this lipase.

\section{Acknowledgments}

We acknowledge financial support from the following Brazilian Granting Agencies: Fundação de Amparo a Pesquisa do Estado de São Paulo (FAPESP) and Conselho Nacional de Desenvolvimento Científico e Tecnológico (CNPq/PIBIC).

\section{References}

1. Malasanos, T. H.; Stacpoole, P. W.; Diabetes Care 1991, 14, 1160.

2. Nielsen, G. L.; Ernst, E.; Schmidt, E. B.; Omega 3 News 1994, 9, 1 .

3. Ackman, R. G.; J. Aquat. Food Prod. Technol. 1996, 26, 5.

4. Minnis, R. C.; Haq, I. U.; Jackson, P. R.; Yeo, W. W.; Ramsay, L. E.; J. Human Nutr. Dietetics 1998, 11, 13.

5. Garcia, D. G.; Food Technol. 1998, 52, 44.

6. Colombo, J.; Shaddy, D. J.; Andreson, C. J.; Blaga, O. M.; Kannaus, K. N.; Kundurthi, S.; Child Development 2004, 75, 1254.

7. Tsuneo, Y.; Tomomasa, S.; Youko, S.; Line, V.; Tamotsu, H.; J. Am. Oil Chem. Soc. 1992, 69, 1104.

8. Shimada, Y.; Maruyama, K.; Okazaki, S.; Nakamura, M.; Sugihara, A.; Tominaga, Y.; J. Am. Oil Chem. Soc. 1994, 71, 951.

9. Nieto, S.; Gutierrez, J.; Sanhueza, J.; Valenzuela, A.; Grasas y Aceites 1999, 50, 111.

10. Carvalho, P. O.; Campos, P. R. B.; Noffs, M. D.; Bastos, D. H. M.; Oliveira, J. G.; Acta Farma. Bonaer. 2002, 21, 85.

11. Okada, T.; Morrissey, M.T.; Food Chem. 2007, 103, 1411.

12. Breivik, H.; Haraldsson, G. G.; Kristinsson, B.; J. Am. Oil Chem. Soc. 1995, 74, 1425.

13. Wanasundara, U. N.; Shahidi, F.; J. Am. Oil Chem. Soc. 1998, 75, 1767.

14. Gunstone, F. D.; J. Sci. Food Agric. 1999, 79, 1535.

15. Campos, P. R. B.; Oliveira, B. F.; Noffs, M. D.; Carvalho, P. O.; Lecta 2002, $20,7$. 
16. Carvalho, P. O.; Contesini, F. J.; Almeida, A. P.; Macedo, G. A.; Food Biotechnol. 2005, 19, 183.

17. Carvalho, P. O.; Contesini, F. J.; Ikegaki, M.; Braz. J. Microbiol. 2006, 37, 329.

18. Liu, S.; Zhang, C.; Hong, P.; Ji, H.; Food Chem. 2007, 103, 1009.

19. Cheong, L. Z.; Tan, C. P.; Long, K.; Yusoff, M. S. A.; Arifin, N.; Lo, S. K.; Lai, O. M.; Food Chem. 2007, 105, 1614.

20. Stuer, W.; Jaeger, K. E.; Winkler, U. K.; J. Bacteriol. 1986, 168 , 1070.

21. AOCS; Official Methods and Recommended Practices of the American Oil Chemist's Society; AOCS: Champaign, IL, 1998.
22. Hartman, L.; Lago, R.C.A.; Lab. Pract. 1973, 22, 475.

23. Fregolente, L. V.; Batistella, C. B.; Maciel-Filho, R.; WolfMaciel, M. R.; J. Am. Oil Chem. Soc. 2005, 82, 673.

24. Nwosu, C. S.; Boyd, L. C.; J. Food Lipids 1997, 4, 65.

25. Tanaka, Y.; Hirano, J.; Funada, T.; J. Am. Oil Chem. Soc. 1992, $69,1210$.

26. McNeill, G. P.; Moore, S. R.; Ackman, R. G.; J. Am. Oil Chem. Soc. 1996, 73, 1403.

Received: February 29, 2008

Web Release Date: November 26, 2008

FAPESP helped in meeting the publication costs of this article. 